\title{
Evidence of ozone-induced visible foliar injury in Hong Kong using Phaseolus vulgaris as an ozone bioindicator
}

\author{
Felix Leung ${ }^{1 *}$, Jacky Y. S. Pang ${ }^{1}$, Amos P. K. Tai ${ }^{1,2}$, Timothy Lam ${ }^{1}$, Donald K. C. Tao ${ }^{1}$, Katrina \\ Sharps $^{3}$ \\ 1 Earth System Science Programme, Faculty of Science, and Institute of Environment, Energy and \\ Sustainability, The Chinese University of Hong Kong, Sha Tin, Hong Kong; felix.leung@cuhk.edu.hk (F.L.); \\ jackypangys@link.cuhk.edu.hk (J.P.), t1493@exeter.ac.uk (T.L.), DonaldTao@link.cuhk.edu.hk (D.T.) \\ 2 State Key Laboratory of Agrobiotechnology, The Chinese University of Hong Kong, Sha Tin, Hong Kong; \\ amostai@cuhk.edu.hk (A.T.) \\ 3 Centre for Ecology and Hydrology, Deiniol Road, Bangor, Wales, United Kingdom, LL57 2UW; \\ katshar@ceh.ac.uk (K.S.) \\ * Correspondence: felix.leung@cuhk.edu.hk; Tel.: (+852 39437257)
}

\begin{abstract}
Background: Hong Kong is one of the most densely populated cities in the world, with millions of people exposed to severe air pollution. Surface ozone, mostly produced photochemically from anthropogenic precursor gases is harmful to both human and vegetation. The phytotoxicity of ozone has been shown to damage plant photosynthesis, induce early leaf death and retard growth. (2) Methods: We use genotypes of bush bean Phaseolus vulgaris with various degrees of sensitivity to ozone to investigate the impacts of ambient ozone on the morphology and development of the bean. We use ozone-induced foliar injury index and measure the flowerings and fruit production to quantify the ozone stress on the plants. (3) Results: We expected that the ozone-sensitive genotype would suffer from a reduction of yield. Results however show that the ozone-sensitive genotype suffers higher ozone-induced foliar damage as expected but produces more pods and beans and heavier beans than the ozone-resistant genotype. (4) Conclusions: It is postulated that the high ozone sensitivity of the sensitive genotype causes stress-induced flowering and therefore results in higher bean yield. A higher-than-ambient concentration of ozone is needed to negatively impact the yield production of the ozone-sensitive genotype. Meanwhile, ozone-induced foliar damage shows a graduated scale of damage patterns that can be useful for indicating ozone levels. This study demonstrates the usefulness of bioindicators to monitor the phytotoxic effects of ozone pollution in a subtropical city such as Hong Kong.
\end{abstract}

Keywords: ozone pollution; bioindicator; Phaseolus vulgaris

\section{Introduction}

Ground-level ozone $\left(\mathrm{O}_{3}\right)$ is one of the main air pollutants that substantially threatens not only human health but also plant productivity [1-5]. The level of $\mathrm{O}_{3}$ has been increasing particularly in Asia, especially in China where the rate of urbanization and industrialization increases significantly in the last two decades [6]. One of the most economically developed and urbanized region in China is the Pearl River Delta, which is situated in South China on the Pearl River Delta and has a population of around 67 million and a density of 1200 people per $\mathrm{km}^{2}$, with $\mathrm{O}_{3}$ exposure to people being among the highest [7]. Hong Kong as a key economic hub of the region is one of the most densely populated cities in the world but it also has one of the highest ratio of natural vegetation cover, which occupies $\sim 40 \%$ of the landmass of Hong Kong [8], the highest compared to other cities within the region. Its subtropical climate and high percentage of natural vegetation cover enable a high level of biodiversity, supporting numerous plant and invertebrate species that are endemic to Hong Kong. However, there are no studies on how $\mathrm{O}_{3}$ pollution affects the terrestrial ecosystems and vegetation 
in Hong Kong, and very few on similar subtropical cities worldwide either. Here we use a bioindicator species Phaseolus vulgaris to investigate the impacts of ambient $\mathrm{O}_{3}$ pollution on vegetation in Hong Kong.

The most significant direct effects of $\mathrm{O}_{3}$ are on plant growth and leaf physiology. Since plants are the primary producers in terrestrial ecosystems, $\mathrm{O}_{3}$ damage to plants can scale up to higher trophic levels and cause indirect effects. The flux of $\mathrm{O}_{3}$ into the leaf is regulated by a series of aerodynamic, boundary layer and surface resistances, and is ultimately controlled by leaf openings called stomata. The $\mathrm{O}_{3}$ flux varies greatly through space and time with meteorological conditions and plant ecophysiology [9]. The $\mathrm{O}_{3}$ impact on a leaf depends on the detoxification capacity for the incoming $\mathrm{O}_{3}$ flux. There are two modes of action of $\mathrm{O}_{3}$ within the leaf. At high exposure to $\mathrm{O}_{3}$, the flux overwhelms the detoxification capacity and most of the $\mathrm{O}_{3}$ is not detoxified, causing direct damage to the leaf. At a low exposure of $\mathrm{O}_{3}$, it may induce the defense reactions and gene expression in the plants, which require energy to regenerate antioxidants and de novo synthesis (synthesizing complex molecules from simple molecules), ultimately resulting a decreased carbon assimilation rate for plant growth [9]. When integrated over time, the direct impact of tropospheric $\mathrm{O}_{3}$ on plant net primary productivity (NPP) is determined by the rate of $\mathrm{O}_{3}$ penetration into the leaf (the instantaneous and cumulative stomatal $\mathrm{O}_{3}$ flux) and the leaf tolerance to reactive oxygen species (ROS) generated by $\mathrm{O}_{3}$ oxidization [3].

On a biochemical level, $\mathrm{O}_{3}$ impact to a leaf can be evaluated by the reactions of $\mathrm{O}_{3}$ with different plant components. The first barrier against $\mathrm{O}_{3}$ entering the intercellular space of the mesophyll is the stomatal aperture. Once $\mathrm{O}_{3}$ reaches the intercellular space, it reacts with chemicals in the apoplast and produces ROS such as hydrogen peroxide and hydroxyl radicals, which stimulate the production of ascorbic acid (ABA), acting as the first line of defense against $\mathrm{O}_{3}$ damage [10-12]. With acute exposure to a high level of $\mathrm{O}_{3}(>150 \mathrm{ppb})$ stress response of the plant would be activated; ROS, stress hormones, $\mathrm{Ca}^{2+}$ and mitogen-activated protein kinase (MAPK) will begin to appear through a cascade of signals. The $\mathrm{O}_{3}$ response pathway overlaps with the programmed cell death induced by pathogens because both stresses amplify ROS production. In the long run, it causes early senescence and decrease photosynthesis rate. This visible ozone injury is observed all over the world where $\mathrm{O}_{3}$ concentration is high $[13,14]$. Experiments on the $\mathrm{O}_{3}$ impact on Arabidopsis in a controlled environment $[15,16]$ show that a minimum of a 80-ppb $\mathrm{O}_{3}$ exposure episode is required to trigger the rapid transient decrease in stomatal conductance [17]. However, long-term chronic exposure to low concentration of $\mathrm{O}_{3}$ still causes irreversible damage to leaves. It impairs the stomatal guard cell aperture; the stomata are then unable to close rapidly in response to environmental stimuli. Ozone also further reduces the sensitivity of the stomata to the plant stress hormone (e.g., ABA) signals [10]. This phenomenon implies that when plants are exposed to a drought and $\mathrm{O}_{3}$ stress at the same time, they would continue to lose water through transpiration, resulting in desiccation [18]. The sensitivity of photosynthetic and stomatal biology to $\mathrm{O}_{3}$ varies greatly between species and with the age of individuals [19].

Plants have been widely used as biomonitors and bioindicators for air quality in the past. For example, Trifolium repens is used for air pollution genotoxicity assessment [20]. Moss and lichens are useful for monitoring the level of heavy metal and nitrogen pollution [21-23]. Plants that could grow in a wide range of habitats and with bioaccumulative properties are suitable candidates as bioindicator species, but often microscopic analysis is required to quantify the level of bioaccumulation of certain pollutants such as heavy metal. Ozone pollution on the other hand usually generates visual symptoms on the plant leaves and it is easy to be quantified using naked eyes and relatively simple measurements [24,25]. 
Ozone injury can be divided into acute injury and chronic injury. Acute injury is symptomatic, showing visible symptoms on leaves, while chronic injury is generally less visible and includes changes in growth, yield and fruit quality $[26,27]$. Surface $\mathrm{O}_{3}$ causes visible injury on plants, impairs photosynthesis, generally reduces yield and growth, and intervenes with the interactions of plants with diseases and pests [28]. On a global scale, $\mathrm{O}_{3}$ pollution reduces the carbon uptake of forests (e.g., $[29,30]$ ) and also poses significant threats to food security because of crop yield reductions (e.g., $[1,2,31])$. Visible injury of leaves due to $\mathrm{O}_{3}$ is an easily observable characteristic that indicates the $\mathrm{O}_{3}$ level in the environment [24]. It is a valuable tool for $\mathrm{O}_{3}$ impact assessment as it indicates the relative $\mathrm{O}_{3}$ stress of the species [32-34].

Each species displays a distinctive visible foliar $\mathrm{O}_{3}$ injury patterns [24]. Bush bean (Phaseolus vulgaris L.) is chosen in this study because it displays a distinctive red or bronze mottle pattern on the leaves. It also has a wide geographical distribution, able to grow in tropical, subtropical and temperate climates. It has a short growing season of around four months and is able to produce more easily quantifiable results of ozone impact via measuring the $\mathrm{O}_{3}$ foliar injury and yield. Bush bean is also a common edible bean found in the diets of many cultures, and thus the visible impacts of its damage by ozone can more relevantly be translated to implications for food security.

Here we investigate how ambient $\mathrm{O}_{3}$ affects the phenotypic and developmental differences between two genotypes of a single cultivar of Phaseolus vulgaris. Our objectives are to demonstrate the impacts of ambient $\mathrm{O}_{3}$ exposure on the development of bush bean and its usefulness as a biomonitor and bioindicator for $\mathrm{O}_{3}$ pollution in a subtropical city, and to develop a framework to approximate $\mathrm{O}_{3}$ concentration of an environment where accurate measurements are unavailable by measuring the visible $\mathrm{O}_{3}$ foliar injury.

\section{Experiments}

\subsection{Plant materials and gardening}

This study uses the ozone-sensitive (S156) and ozone-resistant (R123) genotypes of Phaseolus vulgaris (bush bean, French dwarf bean) that have been selected at the United States Department of Agriculture - Agricultural Research Service (USDA-ARS) Plant Science Unit field site near Raleigh, North Carolina, USA. The bean lines were developed from a genetic cross reported by Dick Reinert as described in Reinert and Eason (2000) [35]. Individual sensitive (S) and tolerant (R) lines were identified, the S156 and R123 lines were selected, and then tested in a bioindicator experiment reported in Burkey et al. (2005) [36]. This system has been tested in central and southern parts of Europe since 2008. Burkey et al. (2005) of USDA-ARS kindly provided seeds for the trials [37].

We follow the Bean Biomonitoring Protocol from International Cooperative Programme on Effects of Air Pollution on Natural Vegetation and Crops (ICP vegetation) [37] for growing and recording bean growth. An ozone garden was established inside the campus of The Chinese University of Hong Kong in an experimental plot called the Gene Garden (latitude $22.4248^{\circ}$, longitude $114.2068^{\circ}$ ). It is considered as a rural area as there is only one building nearby situated $50 \mathrm{~m}$ apart. The plot is fenced to prevent mammals such as wild boars or macaques from entering and eating the plants.

For the 2018 trial growth, we grew 16 individual bean plants, with eight of them being sensitive and eight being resistant. The beans first germinated in July in a set of biodegradable pots, which are 6 $\mathrm{cm}$ wide and $4 \mathrm{~cm}$ deep, indoor with adequate watering. When the primary leaves emerged we placed the biodegradable pot into a large pot that is 15 liter in volume with a surface diameter of $25 \mathrm{~cm}$, filled with peat soil and black soil. For the 2019 experimental growth, we germinated the beans in two big pots for each genotype with soil mixture of $50 \%$ peat soil and $50 \%$ sand. When the primary leaves emerged, we transplanted the seedlings carefully to another large pot. There were 12 sensitive and 15 resistant beans that successfully germinated. An insect-proof net was put over the two rows of beans to minimize insect damage. The large pots were lined up and fit with an automatic watering system developed by B-Hyve, which is widely used in commercial farming. A timer was set to water the beans every morning at 8:45am for 1 minute. 


\subsection{Ozone monitoring and meteorological measurements}

We monitor the ozone concentration in the ozone garden using Teledyne ozone analyser Model 400A UV Absorption. The analyser used a system based on the Beer-Lambert law for measuring low concentration of $\mathrm{O}_{3}$ in ambient air. The ambient $\mathrm{O}_{3}$ concentration is detected from the internal electronic resonance of $\mathrm{O}_{3}$ molecules using absorption of $254 \mathrm{~nm}$ UV light emitted from an internal mercury lamp [38]. It provides accurate measurement up to $0.1 \mathrm{ppb}$ and the data are logged for every 5 minutes. The machine is placed in a shed nearby the beans, and a Teflon tube is extended to the outdoor near the beans.

We also measure local meteorological variables using the Vantage Due Pro 2 weather station installed on the field site. Wind speed $\left(\mathrm{m} \mathrm{s}^{-1}\right)$, wind direction (degree ${ }^{\circ}$ from north), temperature $\left({ }^{\circ} \mathrm{C}\right)$, precipitation $(\mathrm{mm})$, air pressure $(\mathrm{hPa})$, radiation $\left(\mathrm{W} \mathrm{m}^{-2}\right)$ and relative humidity $(\%)$ are recorded every 5 minutes.

\subsection{Insect injury monitoring}

From our trial study, we found that many plants suffered from various degrees of insect injury on the leaves, and insect injuries are an important indicator of plant health, complicating the observation and interpretation of ozone injury. We recorded the amount of insect damage by observing the percentage of leave that are missing from the trifoliates ( 3 sub-leaves). It is divided into 4 categories: no damage, $1-5 \%$ damage, $6-25 \%$ and over $25 \%$ damage.

(a)

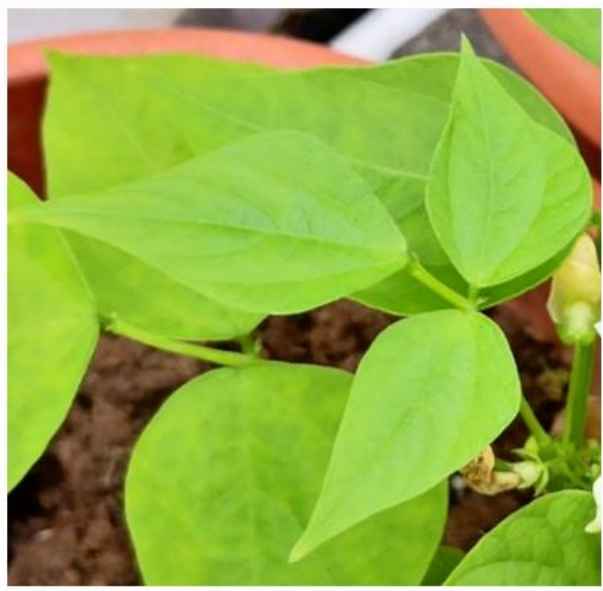

(c)

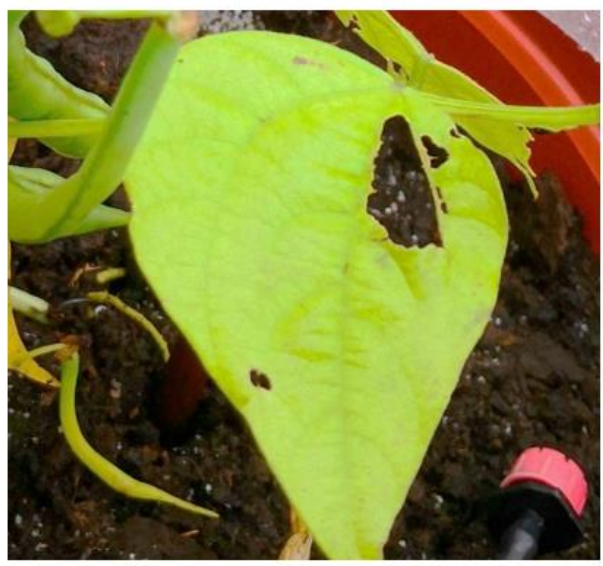

(b)

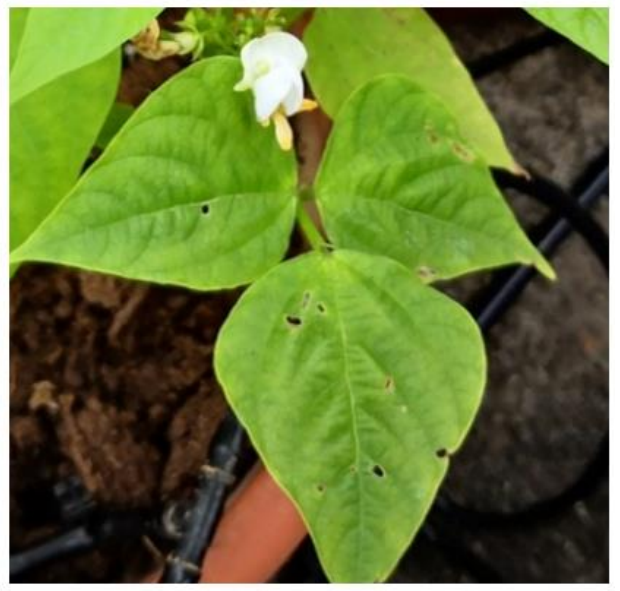

(d)

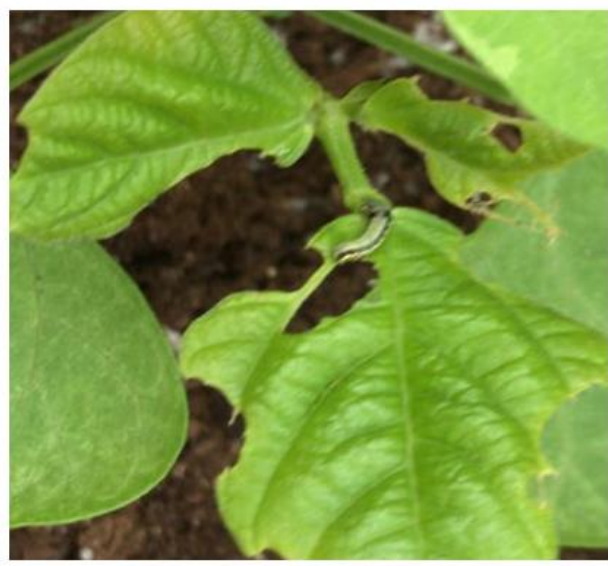

Figure 1. Insect injury index for bush bean: (a) no injury, (b) less than $5 \%$ insect injury, (c) 5 to $25 \%$ insect injury, and (d) larger than $25 \%$ insect injury. We also show in (d) a caterpillar munching the leaf. 


\subsection{Ozone injury monitoring}

According to the Bean Biomonitoring Protocol from ICP vegetation [37], we classify the ozone injury intensity into five categories: without any injuries, larger than $0 \%$ but less than $5 \%$ injury, with 5-25\% injury, with larger than $25 \%$ injury, and with senesced leaves. The ozone injuries on Phaseolus vulgaris are exemplified by some distinctive bronze red dots that appear on the surface of the leaves. Figure 2 shows an example of these five categories of ozone-induced damage on leaves.

(a)

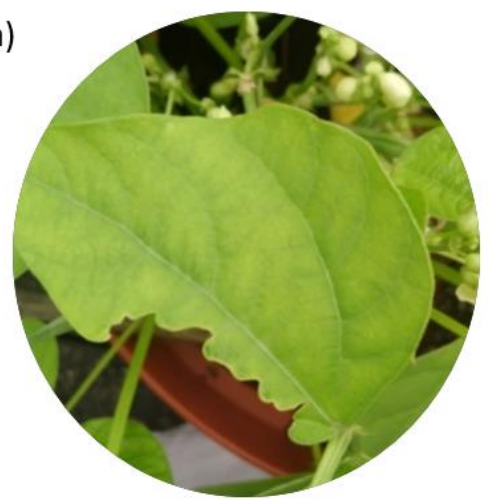

(d)

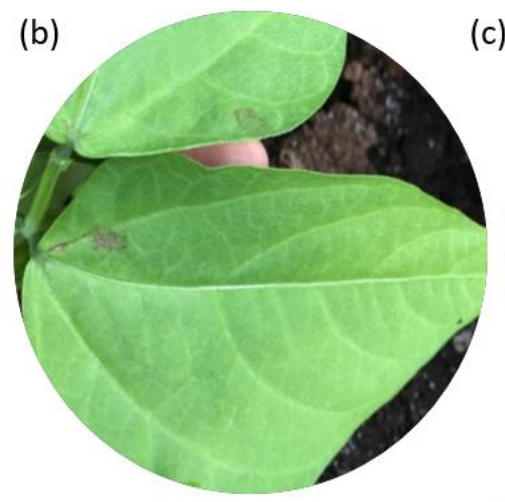

(c)

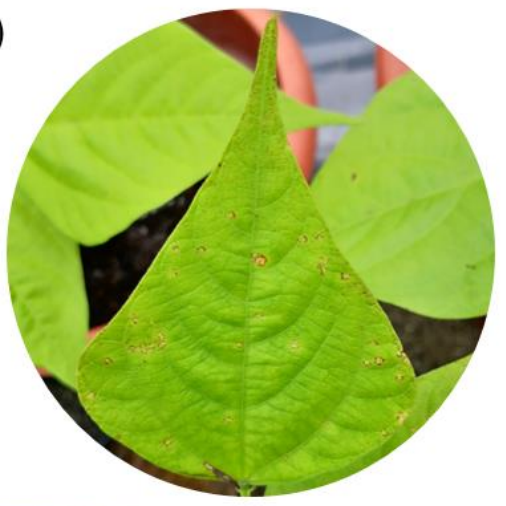

(e)

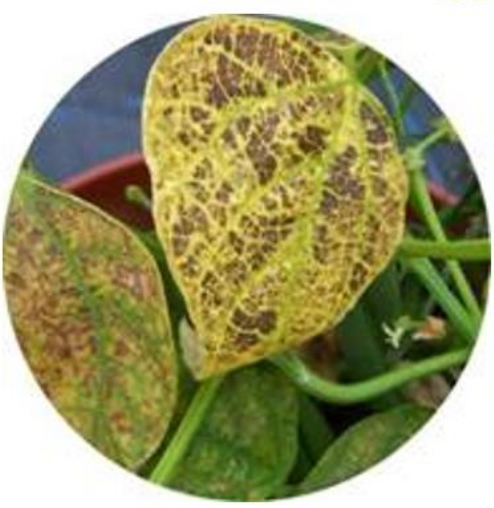

Figure 2. Ozone-induced visible foliar injury index : (a) no $\mathrm{O}_{3}$ injuries but with some insect injury, (b) less than $5 \%$ of ozone injuries on the trifoliates, (c) $5-25 \%$ of bronze patches indicating ozone injury on the leaves, (d) more than $25 \%$ of ozone injuries, and (e) senesced leaf that is yellow instead of green, also showing previous ozone injuries [37].

We compare and contrast the differences between $\mathrm{O}_{3}$-sensitive and $\mathrm{O}_{3}$-resistant beans by quantifying the $\mathrm{O}_{3}$ injuries on leaves. We also measure the number of flowers and pods developed as this information is important for calculating the carbon allocation during flowering. We harvest the beans when $50 \%$ of the pods have turned brown. The pods are weighed to get the wet weight, and then dried in an oven with $40^{\circ} \mathrm{C}$ overnight and weighed again to obtain the dry weight. The number of beans inside each pod is recorded and each bean is weighed individually. We consistently use the Student's $t$-test to determine if the results of the resistant and sensitive genotypes are statistically significantly different.

\section{Results}

The $\mathrm{O}_{3}$ level in the study site was monitored continuously since 2019. The $\mathrm{O}_{3}$ level varied between 40-70 ppb during daytime and with a background $\mathrm{O}_{3}$ level of $10 \mathrm{ppb}$ during night time. It had a peak $\mathrm{O}_{3}$ concentration of $\sim 100 \mathrm{ppb}$ in early April. The plants were exposed to $\mathrm{O}_{3}$ concentration that exceed $60 \mathrm{ppb}$ for 22 days, with two days on which the $\mathrm{O}_{3}$ concentration exceeded $80 \mathrm{ppb}$. 
(a)

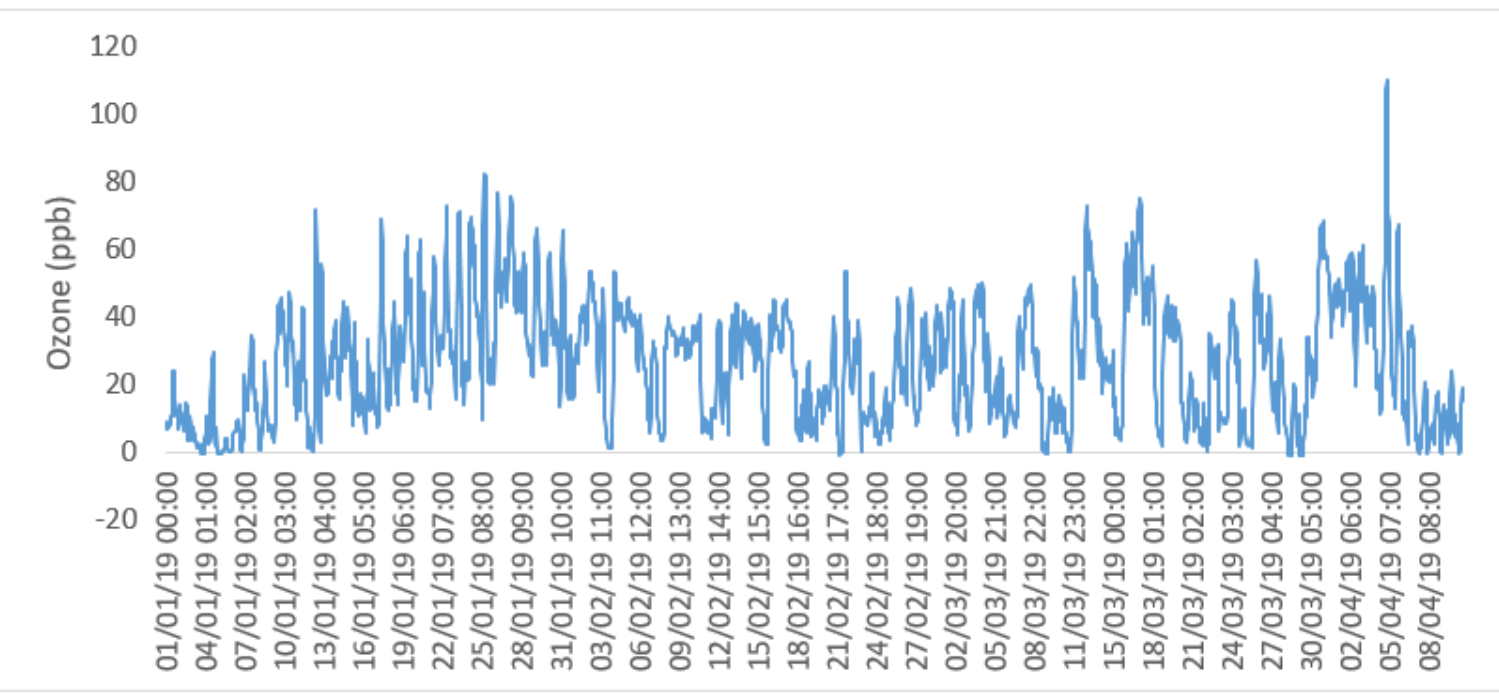

(b)

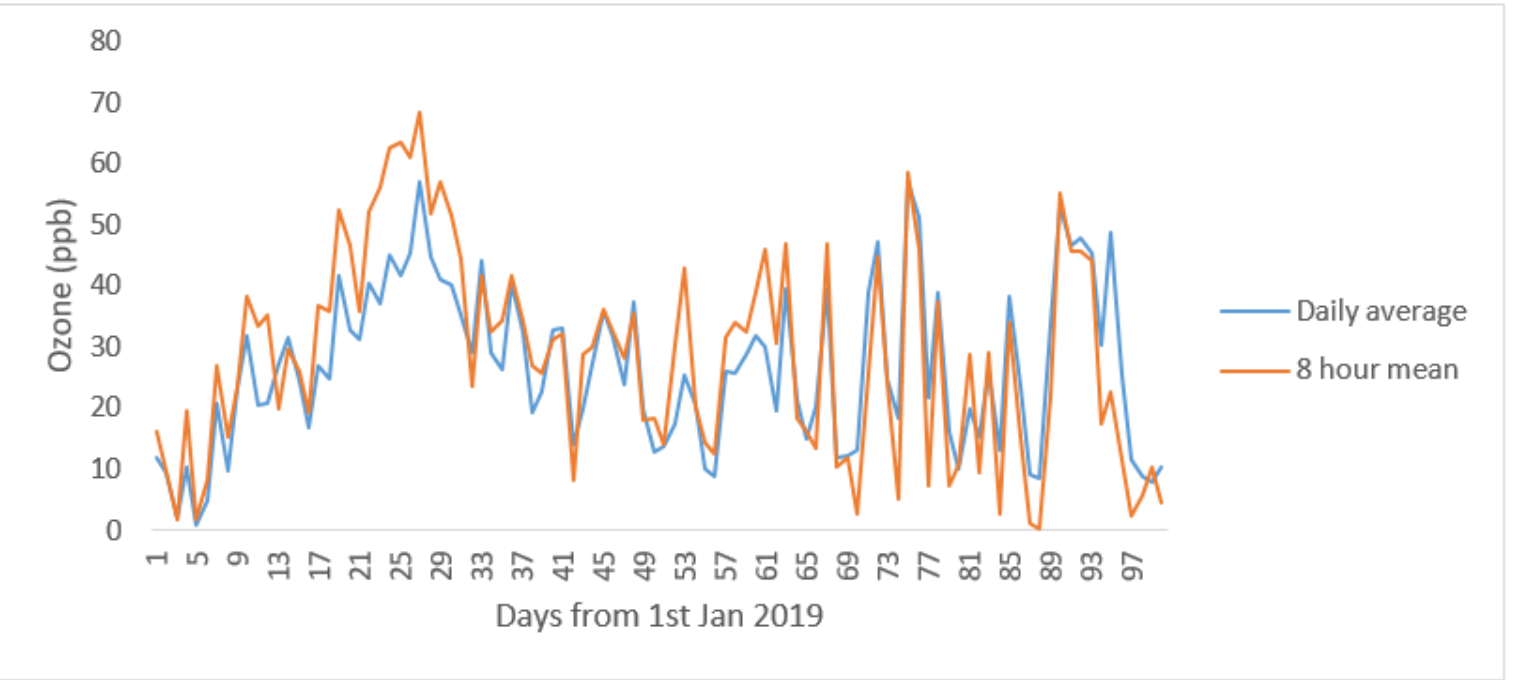

Figure 3. (a) Hourly ozone level in ppb, and (b) daily mean ozone and 8-hour mean ozone recorded at the Ozone Garden (latitude 22.4248 ${ }^{\circ}$, longitude 114.2068 ) from 1 ${ }^{\text {st }}$ Jan to 20th April 2019 using Teledyne 400 ozone analyzer.

To track the age of the plant, we measured the germination dates of the beans. Fig. 4 shows that the sensitive genotype takes a longer time (median of 77.5 days) to complete the life cycle than the resistant genotype (median of 73 days). In addition, it takes a slightly longer time for sensitive genotype to reach its flowering stage (median of 40 days) than resistant genotype (median 35 days). 
(a)

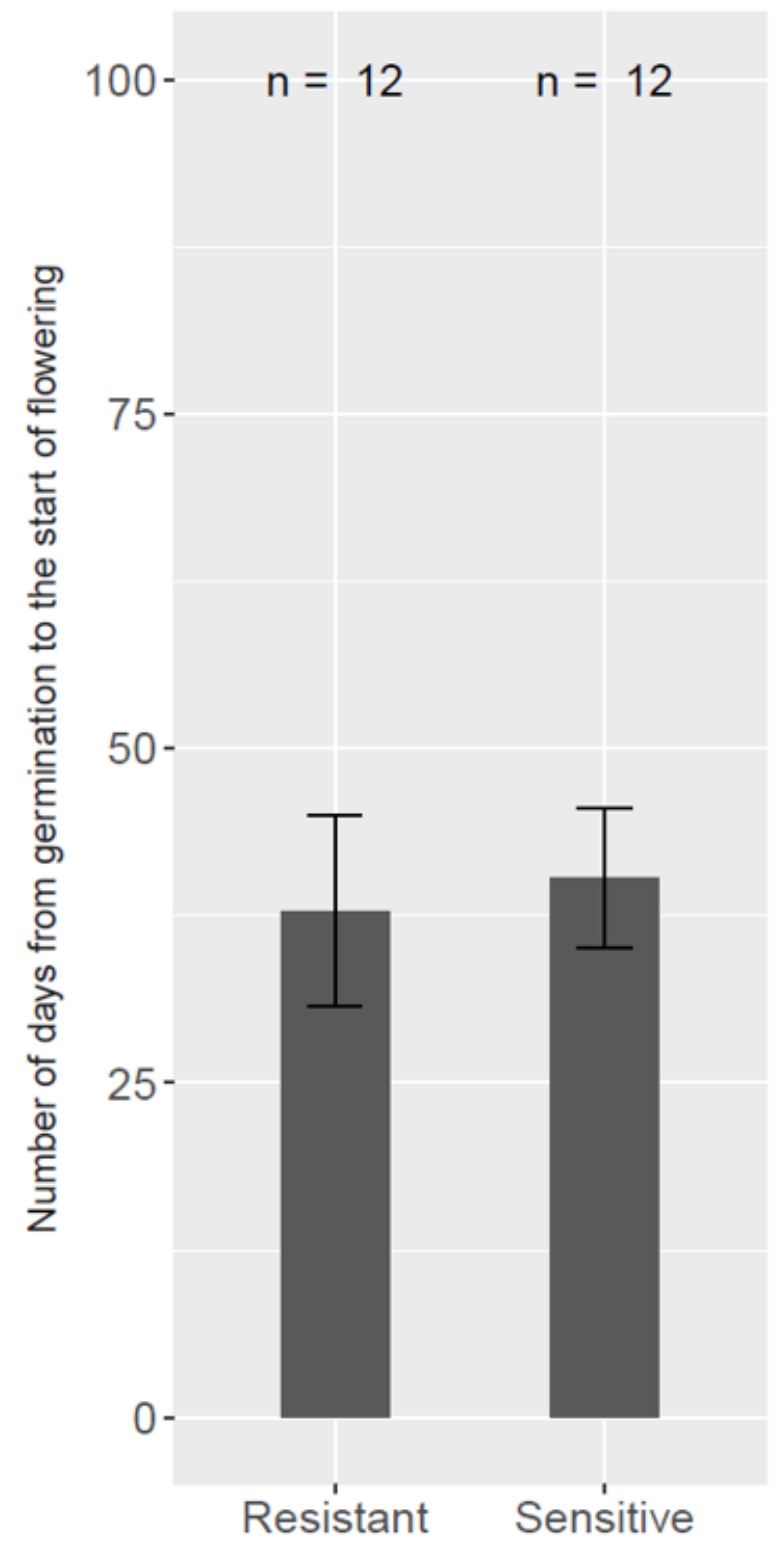

(b)

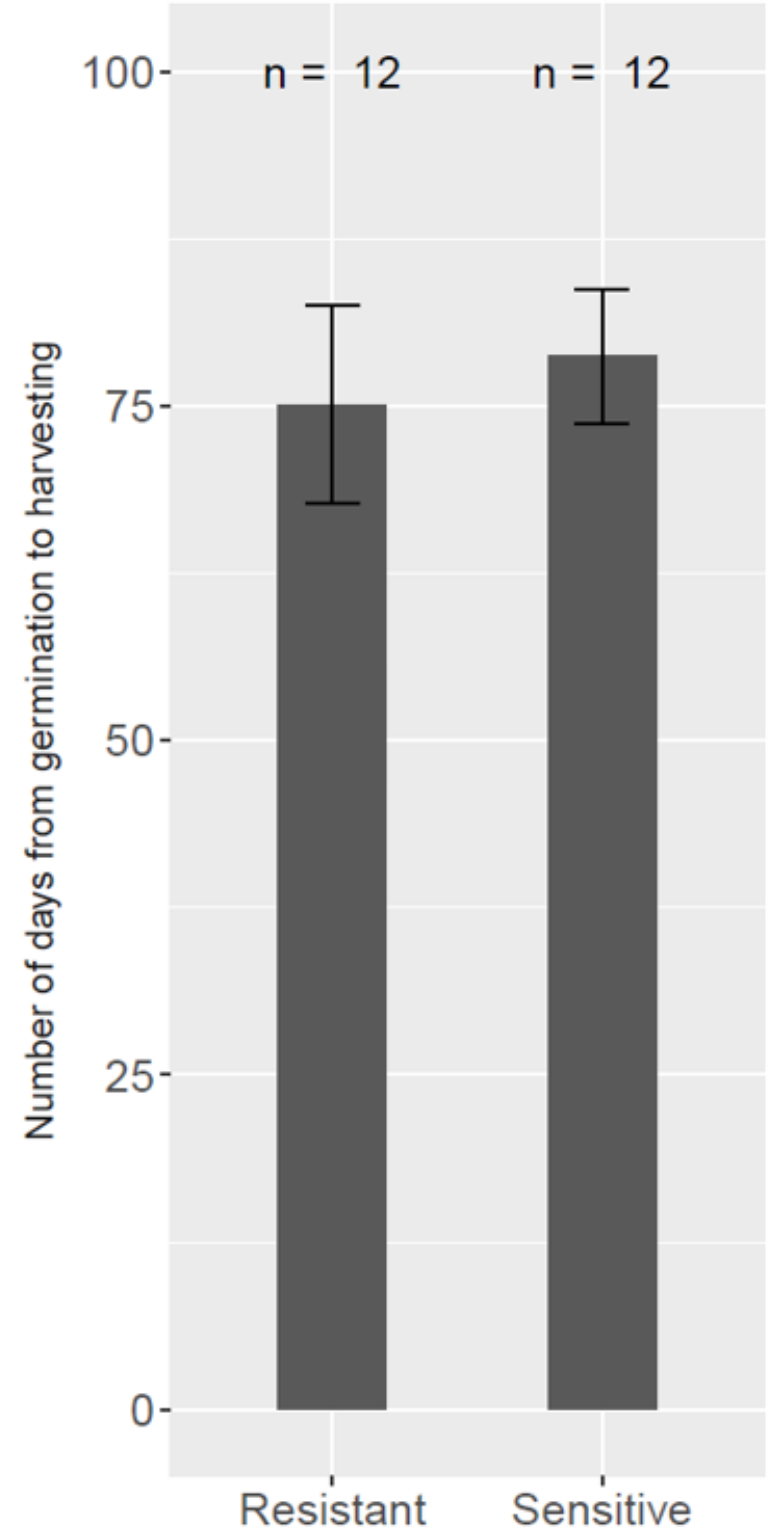

Figure 4. Days for the resistant and sensitive genotype of Phaseolus vulgaris in completing the life cycle from germination to (a) complete harvest and (b) maximum number of flowering. $\pm 1 \sigma$ standard deviation is showed. 

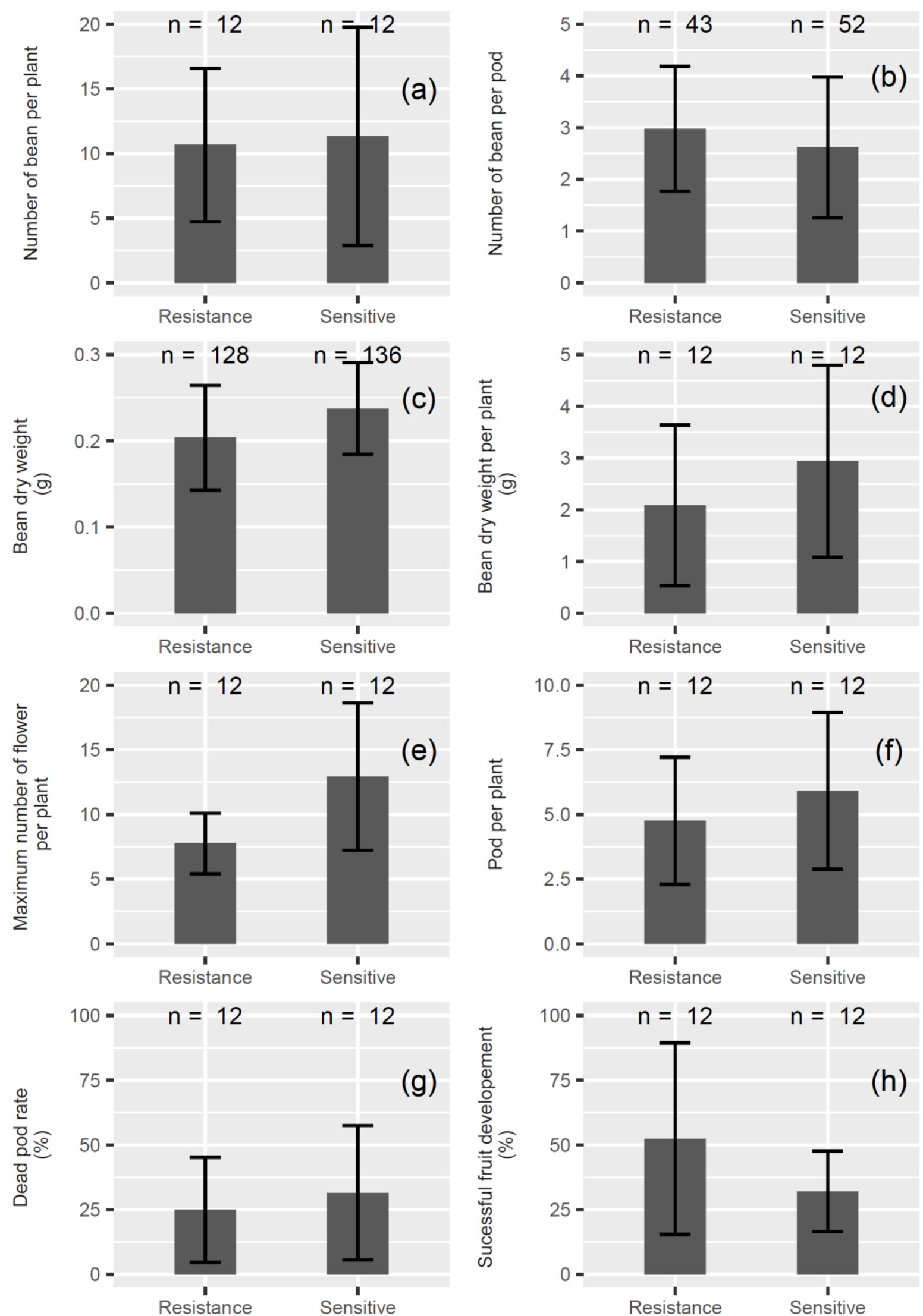

Figure 5. (a) Number of beans per plant, (b) beans per pod, (c) average weight of beans, (d) total weight of beans per plant ( $p$-value $<0.05$ ), (e) maximum number of flowers produced in each plant ( $p$-value $<0.05)$, (f) number of pods per plant, $(\mathrm{g})$ percentage of dead pod within total number of pods, and $(h)$ percentage of pods that have beans compared to maximum number of flowers for sensitive and resistant genotype of Phaseolus vulgaris . $\pm 1 \sigma$ standard deviation is showed. 
The median of the total flowers grown per plant is 12 for the sensitive genotype while for the resistance genotype it is 7.5. The sensitive genotype has statistically significantly ( $p$-value $<0.05$ ) higher number of maximum flowers than the resistant genotype. The higher number of flowering for the sensitive genotype also leads to a higher number of fruiting (Fig. 5), with a median of 5.1 pod per plant which is higher than the resistant one which has a median of 4.6. However, the sensitive genotype also has a higher ratio of pod that does not develop any beans (30\%), which is higher than that for the resistant genotype (20\%).

The number of average beans per plant and average number of beans per pod are not significantly different between the sensitive and resistant genotype according (Fig. 5). The median number of beans per pod are the same for both genotypes, which is three beans per pod. The median number of beans per plant for the resistant and sensitive genotype is 8.5 and 9.5, respectively, but the average number for the resistant genotype is higher, which is due to some individual plants with an unusually high number of beans. According to Fig. 5(c), the sensitive genotype has a significantly ( $\mathrm{p}$-value $<0.05)$ heavier beans $(0.24 \mathrm{~g})$ than the resistant one $(0.20 \mathrm{~g})$, and it leads to an overall higher total bean yield for the sensitive (median of $2.18 \mathrm{~g}$ ) than resistant genotype (median of $1.37 \mathrm{~g}$ ) according to Fig. 5(g). However, the variations among the sensitive beans are higher, with some plants that have all harvest destroyed by pest, causing no yield at all.

In brief, we find that the bean weight and maximum number of flowers are the only parameters that display significant differences between the sensitive and resistant genotypes. Percentage of successful fruit development also gives a close to significant result ( $p$-value $=0.07)$, which is consistent with our hypothesis (Table 1). 
Table 1. Effect of ambient ozone level on resistant and sensitive genotypes of Phaseolus vulgaris

\begin{tabular}{c|ccc}
\multicolumn{1}{c}{} & $\begin{array}{c}\text { Mean for resistant } \\
\text { genotype } \pm 1 \sigma \mathrm{SD}\end{array}$ & $\begin{array}{c}\text { Mean for sensitive } \\
\text { genotype } \pm 1 \sigma \mathrm{SD}\end{array}$ & $p$-value \\
\hline \% Successful Fruit Development & $50.21 \pm 37$ & $35.92 \pm 15.7$ & 0.0772 \\
Total bean weight per plant & $2.09 \pm 1.55$ & $2.69 \pm 1.85$ & 0.4117 \\
Pod per plant & $4.75 \pm 2.45$ & $5.92 \pm 3.02$ & 0.3116 \\
Dead pod rate & $0.25 \pm 0.203$ & $0.31 \pm 0.26$ & 0.5004 \\
Bean dry weight & $0.21 \pm 0.06$ & $0.24 \pm 0.05$ & 0.000012 \\
Bean per pod & $2.98 \pm 1.2$ & $2.62 \pm 1.36$ & 0.1732 \\
Bean per plant & $10.67 \pm 5.93$ & $11.17 \pm 8.45$ & 0.865 \\
Maximum number of flowers & $8.07 \pm 2.34$ & $12.67 \pm 5.7$ & 0.0243 \\
Days to maximum flowering & $37.87 \pm 7.11$ & $40.33 \pm 5.21$ & 0.3087 \\
Days from germination to harvest & $75.13 \pm 7.45$ & $78.75 \pm 5.01$ & 0.1459
\end{tabular}

The overall results show a higher yield for the $\mathrm{O}_{3}$-sensitive beans than the resistant ones; this is consistent with the study by Elagöz \& Manning (2005) [26], in which the sensitive genotype produces heavier beans with a higher variation in bean weight and number of beans per pod. Fig. 5 also shows that resistant genotype has a higher successful rate of fruiting development from flowering to bean formation and less immature or dead pod (Fig. 5(b)) than the sensitive one. This implies that the resistant genotype has a better energy use efficiency in reproduction than the sensitive one. Moreover, it suggests that the resistant plant is able to reach maturation and senescence more consistently than the sensitive one. The consistency of crop development is useful for farmers to predict yield for the coming growing season.

Although the sensitive genotype shows a higher yield than the resistant one, the sensitive genotype shows a higher level of $\mathrm{O}_{3}$-induced visible foliar injury than the resistant one (Fig. 6). $\mathrm{O}_{3}$ injury first appeared as a small patch of mottles on the leaf surface and then more mottles would appear and joined to form a larger patch. The injured leaf later became dried, turned yellowish and senesced eventually. According to Fig. 6, the sensitive plants progress from no injury to larger than $25 \%$ injury more quickly (within one week) than the resistant one (over more than two weeks). The resistant genotype can recover by producing some new leaves from week 8 and it reduces the percentage of leaves that are larger than $25 \%$ injury. This result is consistent with the study by Elagoz et al., (2005) [26], which also showed that higher $\mathrm{O}_{3}$ exposure lead to higher occurrence of $\mathrm{O}_{3}$ injury. 
(a)

(b)
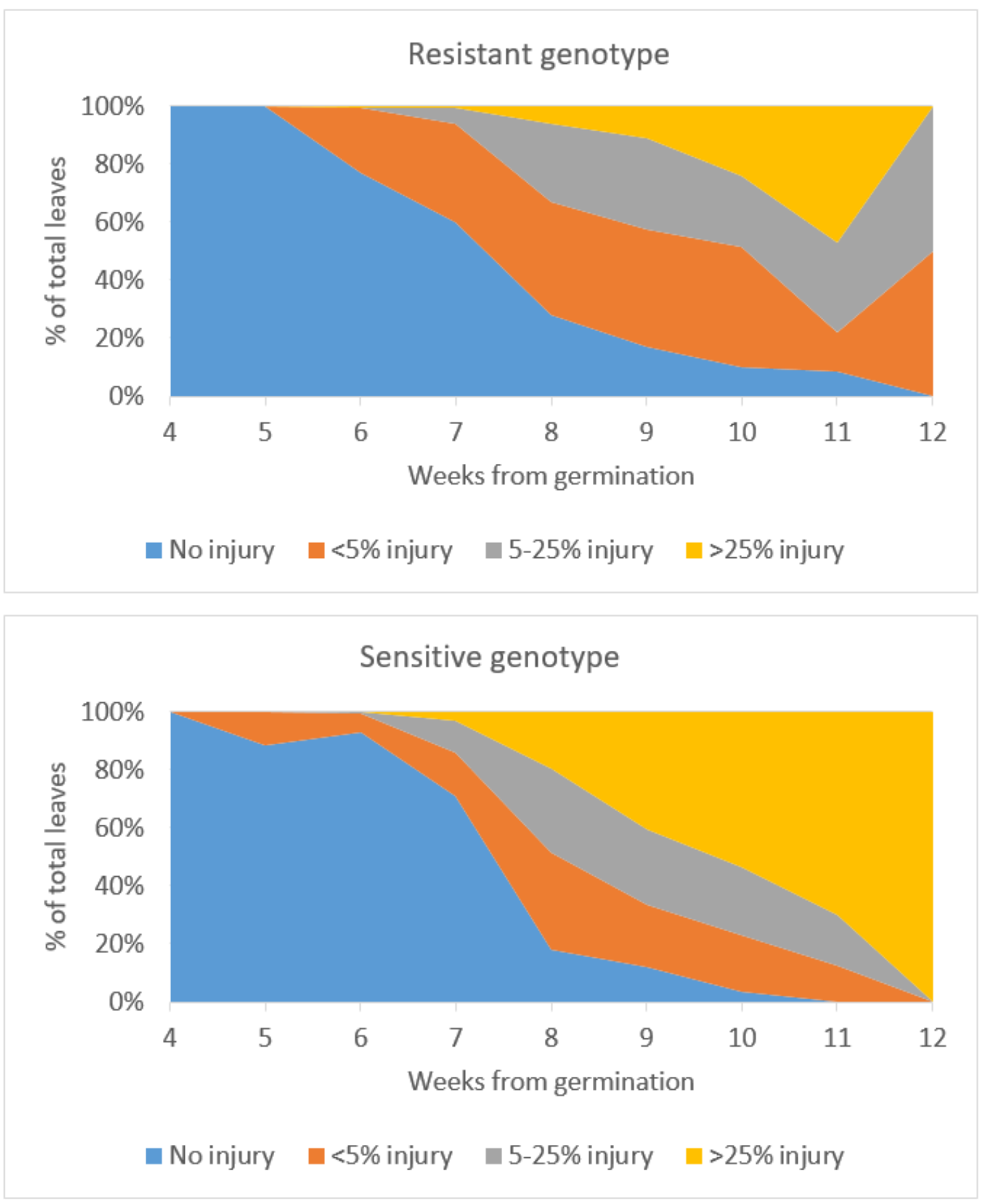

Figure 6. Percentage of $\mathrm{O}_{3}$-induced visible foliar injury according to the injury index from germination to harvest for resistant (a) and sensitive (b) genotype of Phaseolus vulgaris

\section{Discussion}

There are several explanations for more severe $\mathrm{O}_{3}$-induced leaf injury on the sensitive plants but a higher yield than the resistant genotype. Insect injuries were observed throughout the growing period and both resistant and sensitive plant suffered from insect injury on leaves and the pods. An insect proof net was installed but some small caterpillars and leafhoppers were still observed on the plant. We recorded the insect injury index and found no significant differences between the resistant and sensitive genotypes; therefore, insect injuries are not the cause for this phenomenon.

Flowering and fruit development are highly dependent on the environmental factors. When plants experience environmental stress such as poor nutrition, low temperature, high-intensity light, and plant hormone such as phenylalanine ammonia-lyase (PAL) will increase in production and induce flowering [39]. This hormone is known as a flowering stimulus, and the gene responsible for 
the production of PAL has been identified and it exists in many plants [39]. This stress-induced flowering allows the plant to produce more flowers and therefore increase the chance of fertilization and fruiting. It allows the plant to produce more seeds and increases the chance of reproduction when the stress subsides and environmental conditions improve again. $\mathrm{O}_{3}$ would likely be one of the stresses that could induce flowering through this mechanism, and since thus the sensitive genotype may produce more flowers and seeds as a coping mechanism.

The sensitive genotype has a higher stomatal conductance due to its genetic variation $[35,40]$, and therefore more $\mathrm{O}_{3}$ can enter into the stomata because of its higher conductance, and as a result causing more injuries [41,42]. When $\mathrm{O}_{3}$ level is low, the sensitive plant would be more productive as it has higher photosynthesis rate because of faster $\mathrm{CO}_{2}$ uptake through the stomata. However, the plant also takes up $\mathrm{O}_{3}$ through the stomata at the same time, resulting in foliar injuries and possible yield loss. It is likely that the $\mathrm{O}_{3}$ concentration in Hong Kong from January to April might not be high enough for the sensitive genotypes to display a reduction of yield. Our results are indeed consistent with the findings of Burkey et al. (2012) [40], who concluded that under ambient $\mathrm{O}_{3}$ environment, only highly managed plots with optimal nutrients and irrigation are able to detect $\mathrm{O}_{3}$ impact where seasonal mean $\mathrm{O}_{3}$ concentration are less than $50 \mathrm{ppb}$. In our study, since the majority of the growing period had an $\mathrm{O}_{3}$ concentration below 50 ppb (Fig. 1), it is the likely reason why the sensitive genotypes did not show significant yield losses.

The relationship between leaf injury and yield has not been fully understood. It is assumed that less injured leaf has a higher leaf area index (LAI), which would be more productive and produce higher yield. However, recent studies from Srinivasan et al., (2017) showed that cultivar of soybean with lower LAI produces an around $8 \%$ higher yield than the modern cultivar that has higher LAI [43]. This is because the modern cultivar is optimized for producing more leaves instead of a higher yield [43]. This suggests that physically removing a certain amount of leaves or presence of injured leaves would increase the energy use efficiency of crops and therefore increase overall crop yield.

One of the limitations of this study is that we only have 27 individual plants and it might not be able to give a more statistically significant set of results due to a relatively small sample size. Therefore, continuation of the experiment with a larger number of plants is warranted. This study focuses on foliar injuries and yields, but other physiological traits such as stomatal conductance, LAI and photosynthesis rate would be highly useful for a more comprehensively evaluation of $\mathrm{O}_{3}$ impacts on plants in a subtropical city.

Based on the results of this study and generalizing results from previous studies [20,21,36,44], we can devise a framework for using sensitive and resistant Phaseolus vulgaris genotypes to inform about $\mathrm{O}_{3}$ concentration and its phytotoxicity for a great variety of locations (Table 2). This framework would allow gardeners, foresters and farmers to understand and reference $\mathrm{O}_{3}$ pollution impacts on trees and crops easily, and it could provide a useful guideline in estimating $\mathrm{O}_{3}$ concentrations and air quality without continuous and sophisticated pollution monitoring equipment. As part of the growing network of Ozone Gardens worldwide [21,32,37,45-47], the setup of this study will allow a valuable reference for cross-city comparisons of $\mathrm{O}_{3}$ impacts, and contribute to both local and global educational effort to help the public visualize and understand the impacts of air pollution.

Table 2. Framework for using sensitive and resistant Phaseolus vulgaris genotypes as an ozone bioindicator. 


$\begin{array}{llll}\begin{array}{l}\text { Ozone } \\ \text { concentration }(\mathbf{p p b})\end{array} & \text { Air quality } & \text { Resistant } & \text { Sensitive } \\ 0-10 & \text { Very clean } & \text { No visible injury } & \text { No visible injury } \\ 10-30 & \text { Clean } & \text { No visible injury } & \text { Some ozone-induced injury } \\ 30-50 & \text { Moderate } & \text { ozone-induced foliar injury } & \begin{array}{l}\text { ozone-induced injury but } \\ \text { higher yield than resistant }\end{array} \\ 50-80 & \text { Polluted } & \begin{array}{l}\text { ozone-induced injury and same } \\ \text { yield as sensitive }\end{array} & \begin{array}{l}\text { ozone-induced injury and same } \\ \text { yield as resistant }\end{array} \\ >80 & \text { Very polluted } & \begin{array}{l}\text { ozone-induced injury and higher } \\ \text { yield than sensitive [36] }\end{array} & \begin{array}{l}\text { ozone-induced injury and } \\ \text { lower yield than resistant }\end{array}\end{array}$

\section{Conclusions}

In this exploratory study, we find that ambient $\mathrm{O}_{3}$ levels in Hong Kong causes a higher intensity of visible foliar injury on leaves of the sensitive genotype than the resistant genotype of Phaseolus vulgaris. The sensitive genotype also produces higher yield than the resistant one in terms of the number of beans per pod, beans per plant and the weight of beans per plant. The $\mathrm{O}_{3}$ concentration in Hong Kong is high enough to induce foliar injury and the stress-induced flowering and fruiting for sensitive genotypes, but not high enough to create significant yield losses. This study highlights the value of Phaseolus vulgaris as a bioindicator for $\mathrm{O}_{3}$ pollution, with both foliar injury and yield being useful indicators, for the first time in a subtropical city such as Hong Kong.

Author Contributions: All authors were involved in designing and discussing the study. A.T. was the principal investigator of the project. F.L., J.P., D.T. and T.L. collected the required data and undertook the data analysis. F.L. and A.T. drafted the manuscript and contributed to the write-up of the paper. A.T. and K.S. revised the manuscript and edited the language. All authors read and approved the final manuscript.

Funding: This research was funded by the Research Sustainability for Major RGC Funding Schemes of The Chinese University of Hong Kong (Project No.: 3133189) and the Vice-Chancellor's Discretionary Fund of The Chinese University of Hong Kong (Project No.: 4930744).

Acknowledgments: We would like to acknowledge Gina Mills, Harry Harmens, Felicity Hayes and Katrina Sharp from the Centre for Ecology and Hydrology, Bangor, UK for providing the seeds of Phaseolus vulgaris and their support in ICP Vegetation Asia. We would also like to thank the Institute of Environment, Energy and Sustainability, The Chinese University of Hong Kong for supporting this project.

Conflicts of Interest: The authors declare no conflict of interest. The funders had no role in the design of the study; in the collection, analyses, or interpretation of data; in the writing of the manuscript, or in the decision to publish the results. 


\section{References}

1. Tai, A.P.K.; Martin, M.V.; Heald, C.L.Threat to future global food security from climate change and ozone air pollution. Nat. Clim. Chang. 2014, 4, 817-821.

2. Tai, A.P.K.; Val Martin, M.Impacts of ozone air pollution and temperature extremes on crop yields: Spatial variability, adaptation and implications for future food security. Atmos. Environ. 2017, 169, 11-21.

3. Ainsworth, E.A.; Yendrek, C.R.; Sitch, S.; Collins, W.J.; Emberson, L.D.The Effects of Tropospheric Ozone on Net Primary Productivity and Implications for Climate Change. Annu. Rev. Plant Biol. 2012, 63, 637-661.

4. Huntingford, C.; Cox, P.M.; Mercado, L.M.; Sitch, S.; Bellouin, N.; Boucher, O.; A, P.T.R.S.; Gedney, N.Highly contrasting effects of different climate forcing agents on terrestrial ecosystem services. Philos. Trans. A. Math. Phys. Eng. Sci. 2011, 369, 2026-37.

5. Sadiq, M.; Tai, A.P.K.; Lombardozzi, D.; Val Martin, M.Effects of ozone-vegetation coupling on surface ozone air quality via biogeochemical and meteorological feedbacks. Atmos. Chem. Phys. 2017, 17, 3055-3066.

6. Zhao, C.; Wang, Y.; Zeng, T.East China plains: A "basin" of ozone pollution. Environ. Sci. Technol. 2009, 43, 1911-1915.

7. Lu, X.; Hong, J.; Zhang, L.; Cooper, O.R.; Schultz, M.G.; Xu, X.; Wang, T.; Gao, M.; Zhao, Y.; Zhang, Y.Severe Surface Ozone Pollution in China: A Global Perspective. Environ. Sci. Technol. Lett. 2018, 5, 487-494.

8. Ng, E.; Chen, L.; Wang, Y.; Yuan, C.A study on the cooling effects of greening in a highdensity city: An experience from Hong Kong. Build. Environ. 2012, 47, 256-271.

9. The Royal SocietyGround-level ozone in the 21st century: future trends, impacts and policy implications. Sci. Policy 2008, 15, 1-148.

10. Conklin, P.L.; Barth, C.Ascorbic acid, a familiar small molecule intertwined in the response of plants to ozone, pathogens, and the onset of senescence. Plant, Cell Environ. 2004, 27, 959 970.

11. Feng, Z.; Pang, J.; Nouchi, I.; Kobayashi, K.; Yamakawa, T.; Zhu, J.Apoplastic ascorbate contributes to the differential ozone sensitivity in two varieties of winter wheat under fully open-air field conditions. Environ. Pollut. 2010, 158, 3539-45.

12. Turcsányi, E.; Lyons, T.; Plöchl, M.; Barnes, J.Does ascorbate in the mesophyll cell walls form the first line of defence against ozone? Testing the concept using broad bean (Vicia faba L.). J. Exp. Bot. 2000, 51, 901-10.

13. Ashmore, M.R.Assessing the future global impacts of ozone on vegetation. Plant, Cell 
Environ. 2005, 28, 949-964.

14. Emberson, L.D.; Büker, P.; Ashmore, M.R.Assessing the risk caused by ground level ozone to European forest trees: A case study in pine, beech and oak across different climate regions. Environ. Pollut. 2007, 147, 454-466.

15. Li, P.; Mane, S.P.; Sioson, A. a.; Robinet, C.V.; Heath, L.S.; Bohnert, H.J.; Grene, R.Effects of chronic ozone exposure on gene expression in Arabidopsis thaliana ecotypes and in Thellungiella halophila. Plant, Cell Environ. 2006, 29, 854-868.

16. Wrzaczek, M.; Brosché, M.; Salojärvi, J.; Kangasjärvi, S.; Idänheimo, N.; Mersmann, S.; Robatzek, S.; Karpiński, S.; Karpińska, B.; Kangasjärvi, J.Transcriptional regulation of the CRK/DUF26 group of receptor-like protein kinases by ozone and plant hormones in Arabidopsis. BMC Plant Biol. 2010, 10, 95.

17. Vahisalu, T.; Puzõrjova, I.; Brosché, M.; Valk, E.; Lepiku, M.; Moldau, H.; Pechter, P.; Wang, Y.-S.; Lindgren, O.; Salojärvi, J.; et al.Ozone-triggered rapid stomatal response involves the production of reactive oxygen species, and is controlled by SLAC1 and OST1. Plant J. 2010, $62,442-53$.

18. Wilkinson, S.; Davies, W.J.Drought, ozone, ABA and ethylene: new insights from cell to plant to community. Plant. Cell Environ. 2010, 33, 510-25.

19. Lindroth, R.L.Impacts of elevated atmospheric $\mathrm{CO} 2$ and $\mathrm{O} 3$ on forests: phytochemistry, trophic interactions, and ecosystem dynamics. J. Chem. Ecol. 2010, 36, 2-21.

20. Piraino, F.; Aina, R.; Palin, L.; Prato, N.; Sgorbati, S.; Santagostino, A.; Citterio, S.Air quality biomonitoring: Assessment of air pollution genotoxicity in the Province of Novara (North Italy) by using Trifolium repens L. and molecular markers. Sci. Total Environ. 2006, 372, 350359.

21. Klumpp, A.; Ansel, W.; Klumpp, G.; Belluzzo, N.; Calatayud, V.; Chaplin, N.; Garrec, J.P.; Gutsche, H.J.; Hayes, M.; Hentze, H.W.; et al.EuroBionet: A Pan-European biomonitoring Network for Urban Air Quality Assessment. Environ. Sci. Pollut. Res. 2002, 9, 199-203.

22. Scerbo, R.; Ristori, T.; Possenti, L.; Lampugnani, L.; Barale, R.; Barghigiani, C.Lichen (Xanthoria parietina) biomonitoring of trace element contamination and air quality assessment in Pisa Province (Tuscany, Italy). Sci. Total Environ. 2002, 286, 27-40.

23. Urbat, M.; Lehndorff, E.; Schwark, L.Biomonitoring of air quality in the Cologne conurbation using pine needles as a passive sampler - Part I: Magnetic properties. Atmos. Environ. 2004, $38,3781-3792$.

24. Feng, Z.; Sun, J.; Wan, W.; Hu, E.; Calatayud, V.Evidence of widespread ozone-induced visible injury on plants in Beijing, China. Environ. Pollut. 2014, 193, 296-301. 
25. Klumpp, A.; Ansel, W.; Klumpp, G.; Calatayud, V.; Pierre Garrec, J.; He, S.; Peñuelas, J.; Ribas, À.; Ro-Poulsen, H.; Rasmussen, S.; et al.Ozone pollution and ozone biomonitoring in European cities. Part I: Ozone concentrations and cumulative exposure indices at urban and suburban sites. Atmos. Environ. 2006, 40, 7963-7974.

26. Elagöz, V.; Manning, W.J.Responses of sensitive and tolerant bush beans (Phaseolus vulgaris L.) to ozone in open-top chambers are influenced by phenotypic differences, morphological characteristics, and the chamber environment. Environ. Pollut. 2005, 136, 371-383.

27. Krupa, S.V; Manning, W.J.Atmospheric Ozone: Formation and Effects on Vegetation; 1988; Vol. 50 ;.

28. Krupa, S.; McGrath, M.T.; Andersen, C.P.; Booker, F.L.; Burkey, K.O.; Chappelka, A.H.; Chevone, B.I.; Pell, E.J.; Zilinskas, B.A.Ambient Ozone and Plant Health. Plant Dis. 2001, 85, $4-12$.

29. Sitch, S.; Cox, P.M.; Collins, W.J.; Huntingford, C.Indirect radiative forcing of climate change through ozone effects on the land-carbon sink. Nature 2007, 448, 791-4.

30. Lombardozzi, D.; Levis, S.; Bonan, G.; Hess, P.G.; Sparks, J.P.; Lombardozzi, D.; Levis, S.; Bonan, G.; Hess, P.G.; Sparks, J.P.The Influence of Chronic Ozone Exposure on Global Carbon and Water Cycles. J. Clim. 2015, 28, 292-305.

31. Ainsworth, E. a; Yendrek, C.R.; Sitch, S.; Collins, W.J.; Emberson, L.D.The effects of tropospheric ozone on net primary productivity and implications for climate change. Annu. Rev. Plant Biol. 2012, 63, 637-61.

32. Hayes, F.; Mills, G.; Harmens, H.; Norris, D.Evidence of Widespread Ozone Damage to Vegetation in Europe (1990-2006); Bangor, 2007;

33. Mills, G.; Hayes, F.; Simpson, D.; Emberson, L.; Norris, D.; Harmens, H.; Büker, P.Evidence of widespread effects of ozone on crops and (semi-)natural vegetation in Europe (1990-2006) in relation to AOT40- and flux-based risk maps. Glob. Chang. Biol. 2011, 17, 592-613.

34. Schaub, M.; Calatayud, V.; Ferreti, M.; Brunialti, G.; Lovblad, G.; Krause, G.; Sanz, M.J.Assessment of Ozone Injury. Manual on Methods and Criteria for Harmonized Sampling, Assessment, Monitoring and Analysis of the Effects of Air Pollution on Forests; UNECE ICP Forests Programme Co-ordinating Centre: Hamburg, 2010; Vol. 1;.

35. Reinert, R.A.; Eason, G.Genetic Control of O 3 Sensitivity in a Cross Between Two Cultivars of Snap Bean. J. AMER. SOC. HORT. SCI 2000, 125.

36. Burkey, K.O.; Miller, J.E.; Fiscus, E.L.Assessment of Ambient Ozone Effects on Vegetation Using Snap Bean as a Bioindicator Species. Publ. J. Environ. Qual 2005, 34, 1081-1086.

37. ICP VegetationNew Ozone garden project Available online: 
https://icpvegetation.ceh.ac.uk/new-ozone-garden-project-hong-kong (accessed on Nov 27, 2019).

38. TeledyneModel T400 Photometric Ozone Analyzer Manual Available online: http://www.teledyne-api.com/prod/Downloads/T400 Manual - 06870.pdf (accessed on Nov 11, 2018).

39. Wada, K.C.; Takeno, K.Stress-induced flowering. Plant Signal. Behav. 2010, 5, 944-7.

40. Burkey, K.O.; Booker, F.L.; Ainsworth, E.A.; Nelson, R.L.Field assessment of a snap bean ozone bioindicator system under elevated ozone and carbon dioxide in a free air system. 2012.

41. Anav, A.; Proietti, C.; Menut, L.; Carnicelli, S.; DeMarco, A.; Paoletti, E.Sensitivity of stomatal conductance to soil moisture: implications for tropospheric ozone. Atmos. Chem. Phys 2018, 18, 5747-5763.

42. Reiling, K.; Davison, A.W.; Son, V.I.Effects of ozone on stomatal conductance and photosynthesis in populations of Plantago major L; 1995; Vol. 129;.

43. Srinivasan, V.; Kumar, P.; Long, S.P.Decreasing, not increasing, leaf area will raise crop yields under global atmospheric change. Glob. Chang. Biol. 2017, 23, 1626-1635.

44. Pringle, J.; Yu, C.; Sachs, M.; Ellis, R.Assessing ozone damage to cutleaf coneflower in an ozone bioindicator garden. J. Franklin Inst. 2018, 355, 6152-6168.

45. Fishman, J.; Creilson, J.K.; Parker, P.A.; Ainsworth, E.A.; Vining, G.G.; Szarka, J.; Booker, F.L.; Xu, X.An investigation of widespread ozone damage to the soybean crop in the upper Midwest determined from ground-based and satellite measurements. Atmos. Environ. 2010, $44,2248-2256$.

46. Holland, M.; Kinghorn, S.; Emberson, L.; Cinderby, S.; Ashmore, M.; Mills, G.E.; Harmens, H.Development of a framework for probabilistic assessment of the economic losses caused by ozone damage to crops in Europe. ICP Veg. Rep. Defra 2006, 205, 1-62.

47. NASAOzone Bioindicator Garden Available online: https://airquality.gsfc.nasa.gov/ozonebioindicator-garden (accessed on Nov 27, 2019). 